\title{
The use of taxation records in assessing historical floods in South Moravia, Czech Republic
}

\author{
R. Brázdil ${ }^{1,2}$, K. Chromá ${ }^{2}$, L. Ǩezníčková ${ }^{1,2}$, H. Valášek $^{3}$, L. Dolák ${ }^{1,2}$, Z. Stachoñ ${ }^{1}$, E. Soukalová ${ }^{4}$, and \\ P. Dobrovolný ${ }^{1,2}$ \\ ${ }^{1}$ Institute of Geography, Masaryk University, Brno, Czech Republic \\ ${ }^{2}$ Global Change Research Centre, Academy of Sciences of the Czech Republic, Brno, Czech Republic \\ ${ }^{3}$ Moravian Land Archives, Brno, Czech Republic \\ ${ }^{4}$ Hydrometeorological Institute, Brno, Czech Republic
}

Correspondence to: R. Brázdil (brazdil@ sci.muni.cz)

Received: 17 June 2014 - Published in Hydrol. Earth Syst. Sci. Discuss.: 2 July 2014

Revised: - - Accepted: 1 September 2014 - Published: 1 October 2014

\begin{abstract}
Since the second half of the 17th century, tax relief has been available to farmers and landowners to offset flood damage to property (buildings) and land (fields, meadows, pastures, gardens) in South Moravia, Czech Republic. Historically, the written applications for this were supported by a relatively efficient bureaucratic process that left a clear data trail of documentation, preserved at several levels: in the communities affected, in regional offices, and in the Moravian Land Office, all of which are to be found in estate and family collections in the Moravian Land Archives in the city of Brno, the provincial capital. As well as detailed information about damage done and administrative responses to it, data are often preserved as to the flood event itself, the time of its occurrence and its impacts, sometimes together with causes and stages. The final flood database based on taxation records is used here to describe the temporal and spatial density of both flood events and the records themselves. The information derived is used to help create long-term flood chronologies for the rivers Dyje, Jihlava, Svratka and Morava, combining floods interpreted from taxation records with other documentary data and floods derived from later systematic hydrological measurements (water levels, discharges). Common periods of higher flood frequency appear largely in the periods 1821-1850 and 1921-1950, although this shifts to several other decades for individual rivers. A number of uncertainties are inseparable from flood data taxation records: their spatial and temporal incompleteness; the inevitable limitation to larger-scale damage and restriction to the summer half-year; and the different characters
\end{abstract}

of rivers, including land-use changes and channel modifications. Taxation data have considerable potential for extending our knowledge of past floods for the rest of the Czech Republic, not to mention other European countries in which records have survived.

\section{Introduction}

Floods are among the most destructive natural phenomena in the Czech Republic, often leading to loss of human life and great material damage. The number of disastrous floods has recently increased after a relatively flood-poor late 20th century (Brázdil et al., 2005, 2012c), particularly in the last c. 20 years, which were marked by several disastrous flood events: July 1997 (Matějíček, 1998; Matějíček and Hladný, 1999), July 1998 (Hančarová et al., 1999), August 2002 (Hladný et al., 2004, 2005), March-April 2006 (Brázdil and Kirchner, 2007), June-July 2009 (Daňhelka and Kubát, 2009), May-June and August 2010 (Daňhelka and Šercl, 2011) and June 2013 (Šercl et al., 2013). Just like the Czech Republic, many other European countries endured severe floods in the 1990s-2000s period (e.g. Kundzewicz, 2012 and Blöschl et al., 2013 and references therein). Because of the coincidence of this period with recent climate change associated with global warming (Solomon et al., 2007; Stocker et al., 2013), the question seems to be how exceptional this higher flood activity may be in a longer-term context. 


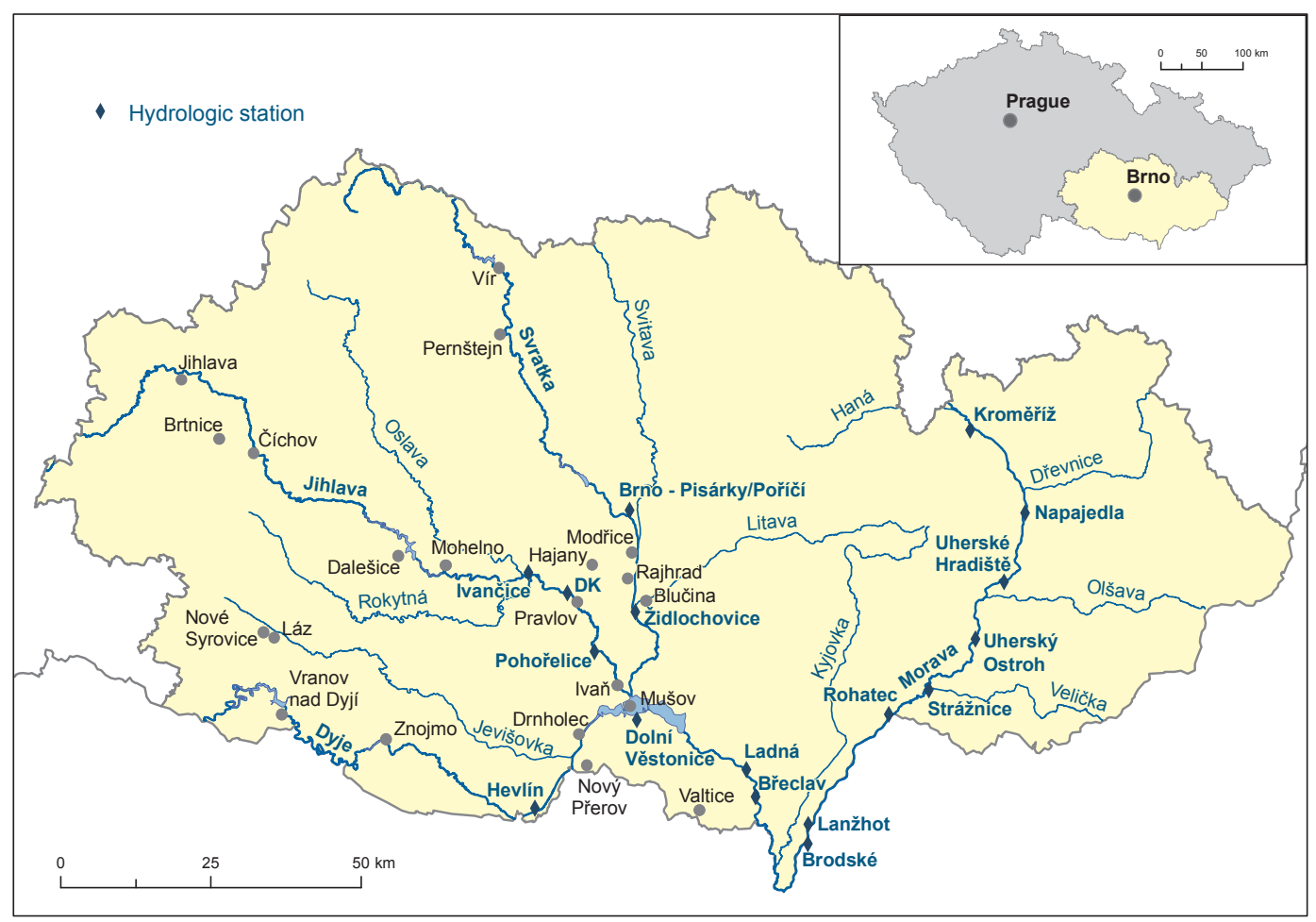

Figure 1. South Moravia with main watercourses, hydrological stations cited and locations mentioned in the text (DK - Dolní Kounice).

Systematic instrumental observations of river water levels and discharges began at different times in different countries, and varied between particular rivers within a given country (Brázdil et al., 2012b). The western (Bohemia) and eastern (Moravia and Silesia) parts of the Czech Republic are examples of this. In Bohemia, the administration in the capital of Prague organised regular water level observations from 1825 onwards; in 1851 these were followed by observations from four further stations on the Vltava and Elbe, the "imperial" rivers. In Moravia, measurement of water stages at times of high water levels was decreed by the Moravian Governorship (Moravské místodržitelství) in August 1877 (with certain exceptions, such as Židlochovice on the River Svratka from 1875). For example, a water gauge was installed in 1877 at Ústí on the River Vsetínská Bečva (Brázdil et al., 2005). However, instrumental observations on the majority of Czech rivers began later (e.g. between the 1880s and 1890s in Moravia).

Knowledge of floods can be extended into the past by investigation of the documentary evidence generated by individuals and institutions that is used in historical hydrology (Brázdil et al., 2006, 2012b and references therein). Various qualitative and quantitative flood information may be obtained from a wide range of such sources, including annals, chronicles, "books of memory" and memoirs, as well as weather diaries, private and official correspondence (letters), special publications, official financial and administrative records, newspapers and journals, sources of a religious nature, chronograms, folk songs (especially those of stall-keepers and markets), pictorial documentation, epigraphic sources, and early instrumental measurements (see Brázdil et al., 2006, 2012b for more details). Recently, taxation records have been added to this list, providing valuable information in several flood studies of the Czech Republic (e.g. Brázdil et al., 2010b, 2011c, 2012a).

Interest in historical hydrology has gathered pace since the 1990s and particularly after 2000, especially in certain European countries. Contributions address individual disastrous floods (Thorndycraft et al., 2006; Kiss, 2009b; Brázdil et al., 2010a; Elleder, 2010; Wetter et al., 2011) or compile and analyse long-term flood chronologies, often combining floods derived from documentary sources with those from continuous hydrological measurements (Sturm et al., 2001; Benito et al., 2003; Mudelsee et al., 2003, 2006; Brázdil et al., 2005, 2011c; Barriendos and Rodrigo, 2006; Glaser et al., 2010; Macdonald and Black, 2010; Schmocker-Fackel and Naef, 2010; Bullón, 2011; Kiss and Laszlovszky, 2013; Macdonald, 2013; Rohr, 2013). These papers usually gather information about the frequency, seasonality, severity, synoptic origins and human impacts of historical floods. They have been supplemented with studies that facilitate calculation of peak flood discharges (Herget and Meurs, 2010; Elleder et al., 2013; Herget et al., 2014; Roggenkamp and Herget, 2014), extending the possibilities of using such knowledge in 
flood risk management. Kjeldsen et al. (2014) reviewed the use of documentary evidence of historical floods in contemporary flood frequency estimations in European countries.

The current paper addresses taxation records kept in the 17th-19th centuries as a source of data for the study of floods in South Moravia, Czech Republic (Fig. 1). This region is an important industrial and agricultural part of the Czech Republic, administered by the country's second largest city, Brno (390000 inhabitants). The Moravian Land Archives in Brno provide a rich source of taxation records that, together with other documentary evidence and good instrumental records, permit a detailed study of past flood patterns. This contribution starts with a basic explanation of the taxation system in Moravia (Sect. 2), lending some insight into data availability and leading to the advantages and weaknesses of using taxation data (Sect. 3). Once certain basic methods of analysis have been addressed in Sect. 4, flood results based on taxation records are presented in Sect. 5. These are followed by a discussion of results in Sect. 6, with particular reference to uncertainties in taxation records and their employment in the creation of long-term flood chronologies. Section 7 provides some concluding remarks.

\section{Taxation system in Moravia}

A brief description of the taxation system in Moravia in the 17th-19th centuries may be helpful in understanding the nature and limitations of the taxation records that include information about flooding (see also Brázdil et al., 2012a; Dolák et al., 2013). The underlying principle was that any damage to property or land resulting from hydrometeorological extremes constituted legitimate grounds for tax relief. The "hidage" system of taxation was introduced in the latter part of the 17th century, in which the "hide" (lán) became the basic unit of land taxation, although it was largely an arbitrary and subjective measure. However, the actual procedure for tax collection changed over time, as discussed below.

\section{(i) The First Moravian Land Registry, 1655}

In this registry it was agreed that "whosoever in the future shall suffer damage due to fire or otherwise, for the purpose of reduction of [taxes due from] hides affected by the damage, [should] report it to the regional administrator who will evaluate it [together] with the neighbours". This was also valid for damage arising out of hydrological or meteorological events. However, only the land worked by "subject people" (rustic, or peasant, land) was subject to tax, while the land held by the nobility (dominical or aristocratic) was exempt from duty (Novotný, 1934).

\section{(ii) The Second Moravian Land Registry, 1675}

This was a revision of the First Registry, intended to eliminate a number of errors but applying the same guidelines (Novotný, 1934).

\section{(iii) The Maria Theresa Land Registry, 1760}

This registry redefined the list of holdings and all other objects liable for land taxes and dues. Based on this list, net profit from peasant homesteads became the basis for the determination of tax. For the first time, a list of dominical (noble) land became liable for taxation. Preparatory work on this registry had started before 26 July 1748 , when a decree including damage by water and weather to houses, barns, fields and yields was proclaimed.

\section{(iv) The Joseph II Land Registry, 1789}

Issued by Joseph II, the eldest son of Maria Theresa, this registry was short-lived, valid only from 1 November 1789 until 1 May 1790. Its aim was to diminish the difference in taxation load between rustic and the dominical land. The community became the fundamental tax unit and individual pieces of land were newly assessed for taxation.

\section{(v) Provisional revision of the Maria Theresa Land Registry, 1820}

The Land Registry of Maria Theresa came into force again in 1790, when the tax dues of both overlord and peasant were standardised. However, on 1 November 1820, a provisional revision came into force for the whole of Moravia. For land tax, this arrangement linked up with a slightly adapted version of the Joseph II Land Registry, with respect to changes in landholders, the extent of land and the agricultural crops grown. A new evaluation of yields also became the basis of taxation (Kocman et al., 1954).

\section{(vi) The Stable Land Registry, 1851}

Continuing unequal taxation of dominical and rustic lands, burgeoning financial demands of the monarchy, and the requirement for clearer specification of tax duty to facilitate tax collection led to further changes in 1851. The Stable Land Registry determined the net profit of lands in terms of an economic quality classification (bonitní tríldy) and the crops grown (Šimek, 1918).

Applications for tax relief after damage arising out of any meteorological or hydrological event followed a standard procedure (Fig. 2). This started with a report by the applicant (e.g. a landowner, the representative of a given settlement, or an individual farmer) to the appropriate regional office, stating what had happened. The original statement included the date of the event, a detailed description of the damage (e.g. the nature of what had been destroyed and the area 
affected) and ended with a request that the commissioners assess the damage. Such requests for tax relief often concluded with how long the applicant would be unable to cultivate the affected land.

The regional administrator then appointed commissioners (usually a regional or estate officer and two tax collectors from neighbouring estates) who personally inspected the places affected (in situ) and made a report confirming or correcting the initial report. The commissioners also submitted their own report to the regional office.

Corresponding damage documents then passed from the regional officer to the Moravian Land Administration (the "Gubernium") in Brno, the body responsible for final decisions. The Gubernium determined the sum of money for tax relief for the affected landholder and specified the period for which tax relief would run. For example, according to a decree proclaimed by Maria Theresa in 1748, tax relief may have been granted for up to 2 or 3 years, depending on the severity of the water damage. Finally, the Gubernium sent its decision to the appropriate regional office and the regional officer transmitted it to the representatives of the landholding.

The documents associated with the various stages of these standard procedures in South Moravia are preserved in a number of collections in the Moravian Land Archives, Brno (a few were also obtained from certain state district archives). The majority of them are classified as estate documents (economic units dedicated to agricultural production). We used a map of South Moravia published by Voldán et al. (1964) that shows the locations of 201 estates in 1848. First, the availability of documents that record hydrometeorological extremes was investigated. This divided estates into three groups: those that still possessed such records $(90$, i.e. $44.8 \%$ of them), those lacking such records (103, or $51.2 \%)$ and those inaccessible to researchers, in other words, those that have not yet been catalogued (8, or $4.0 \%$ ) (Fig. 3). Several smaller parts of South Moravia were included in estates that had administrative centres elsewhere. These were not investigated.

Sometimes the taxation documents for a particular estate also refer to matters on other estates or places located in their neighbourhood. This often occurred when an investigating official reported in situ inspections for adjacent or nearby settlements to a single commission. Information at estate management level could also be supplemented with data based on the plenary processing of taxes for the whole administrative area (particularly within the accountancy departments of regional offices, in which taxes were collated and to which actual sums of money were directed). Unfortunately, much of the material from these institutions has survived only by chance in Moravia (regional offices) (Macek and Žáček, 1958); much deliberate destruction of documents has taken place (Kocman et al., 1954), that is such contemporaneous data appear only sporadically.
However, some taxation data were also preserved in family archives kept by more prominent aristocratic families in Moravia, often the owners of the estates mentioned above. Systematic research into these collections in the Moravian Land Archives in Brno revealed, apart from details about family members, industrial and agricultural business, military matters, and travelling and social events, the taxation records for the time. For example, the Mitrovský family archive contains such records for the Pernštejn estate from 1694 to 1718 (S14), see Brázdil and Valášek (2003).

\section{Data}

\subsection{Taxation data related to floods}

The majority of taxation documents are written in German (in neo-Gothic italic script), while reports in Czech are very rare. The terminology used for floods is relatively simple: "Überschwemmung, Wassergu $\beta$, Wasserfluth, Ergießung". These terms sometimes appear with "Wasserschaden" (water damage) or this term occurs without additional floodidentifying words.

There was a range of types of reports for taxation purposes, from which flood information may now be derived. Basic reports from affected communities provide, as well as a short description of the event, detailed information about damage, specifying exactly which farmers suffered what. An example from Mušov, dated 19 March 1780, reads: "A list of subjects, belonging to the Mušov property of Prince Karl Dietrichstein, who suffered important damage on 9 March 1780 due to inundation by the Svratka, Dyje and Jihlava rivers: [a table with house number, owner's name, and a damage description follows] 3 - Kateřina Lectin - a piece of stable wall to a length of 3 fathoms $[\sim 5.69 \mathrm{~m}]$ fallen $\ldots 17$ - Michael Ruider - 2 fathoms [ $3.79 \mathrm{~m}$ ] of wall fallen and house completely destroyed ...42 - Georg Fischer - house totally inundated ...54 - Johann Georg Beck - the entire house fallen down ..." (S2).

Reports stemming from the formation of a commission to evaluate damage characterise the event in brief, then name the members of the commission and nominate a time and place for the meeting. For example, the regional office in Brno announced on 23 September 1843: "Investigation of water damage suffered by the community of Modrice on 24 August of this year [1843] will be carried out by the appropriate I. R. regional commissioner, Freiherr von Pillersdorf, on 5 October of this year with tax collectors from Hajany and Rajhrad as commission members. The investigation is to start at 9 in the morning, at which time [all] will assemble in the municipal house at Modríice." (S13).

Information about flood events may also be found in the formal grants of tax remission or rebate. For example, a Znojmo regional office report to its administration in Nové Syrovice on 10 October 1828 about damage in the spring of the 


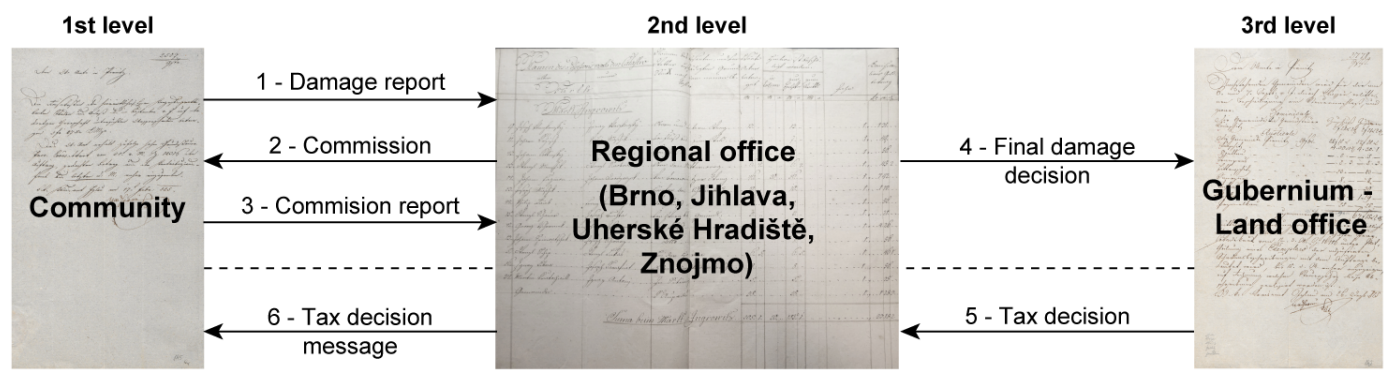

Figure 2. Standard procedure for tax remission and/or rebate.

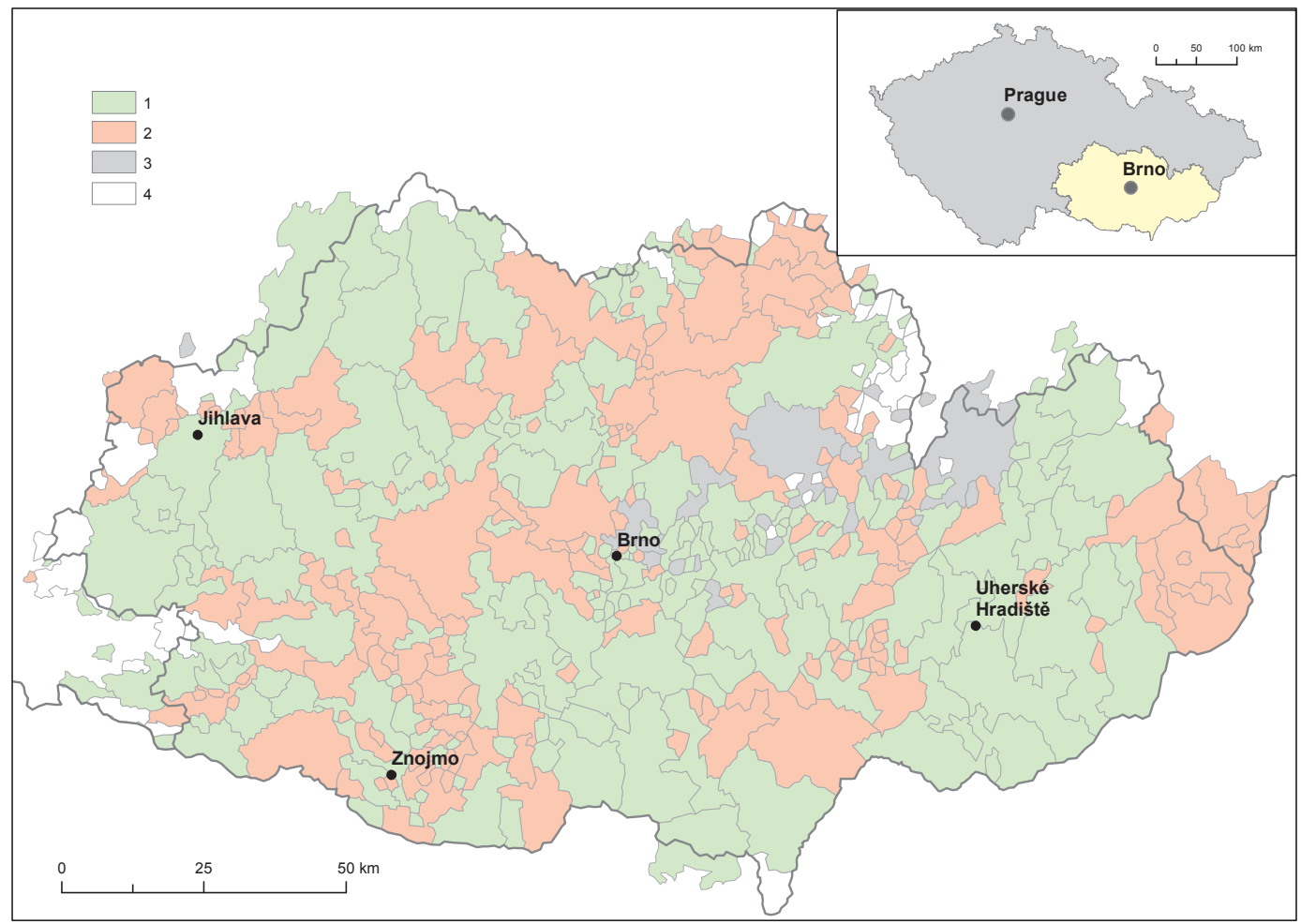

Figure 3. Spatial coverage of estates of South Moravia in 1848 with reference to hydrometeorological extremes (HMEs): (1) with HME records, (2) without HME records, (3) not accessible for research, (4) with administrative centre beyond South Moravia.

same year states: "After corrected and returned statements, a remission of taxes is due to the communities of the Nové Syrovice tax district, affected by water damage, namely to ... [here follows the reported values of land tax and supplementary charges for rustic and dominical lands for the Nové Syrovice and Láz communities] ... a total of 125 gulden $516 / 8$ kreutzer of conventional currency. The land office ... approves that this sum be subtracted from the tax arrears of those people affected or, in the event no arrears exist, from running tax duty." (S11).

Some records give detailed descriptions of the meteorological background to particular flood events. For example, a report from Dolní Kounice for 22 February 1794 relates: "In the night of 15/16 February [1794], as a consequence of a strong, warm southerly wind, the River Jihlava rose to such a terrible height that by the evening of 16 February it burst every bank and flooded all the buildings in the surroundings so deep that even the height of the water during the 1775 flood was not greater; luckily the inundation was not accompanied by ice and so the overflow was less devastating." (S8). Another detailed report from the Židlochovice domain to its owner, dated 16 June 1804 states: "The heavy rain that started on Tuesday [12 June] in the evening continued nearly uninterrupted [up to 16 June], and in the higher mountains perhaps even more intensive, [and] made the water rise to such a height that even the oldest people could not remember ... such a flood [of the River Svratka] in the month of June. Because all the meadows in Pohořelice and 
Ivaň, also Blučina, are under water, the best hay has been destroyed. Prospects for the coming winter are particularly dismal." (S6).

Some requests for help were addressed directly to the owners of the Dolní Kounice domain, as was the case for the Pravlov community, writing to the Prince of Dietrichstein on 27 April 1838: "Our community of Pravlov has been [sic] affected by River Jihlava floods in 1828, 1830 and 1832 in such a way that, due to inundations of this river, many houses have been utterly demolished and more [houses] heavily damaged as well. The residents have constantly attempted to restore their houses ... and have fallen heavily into debt. But now on 7, 8, 9 and 10 March such horrible misfortune occurred that 49 houses were totally destroyed and 30 houses were half-demolished." The request for the help suggested the possibility of buying clinker at trade price and acquiring 25 baulks of oak timber for the repair of damaged water-defence dikes, with postponement of payment for a year (S9).

When especially disastrous events occurred, the taxation records mentions orders for unaffected subjects to help alleviate the consequences of a flood as well as promise to restore the river channel to its original shape. Such a case is recorded for the village of Číchov on the Brtnice estate where, on 23 May 1820, the River Jihlava and another small stream flooded (S1). An interesting report refers to an inundation from the River Morava at Lanžhot where, on 7 March 1846, a list of subjects was prepared who, as part of their manorial labour, were tasked with watching for floods from 27 December 1845 to 8 January 1846, on 27 January, 26 February, 21-28 February and 2-5 March 1846 (S3). However, there is no further report.

Information about floods contained in South Moravian archives is not confined to events in that area. Estate administrations were sometimes asked for financial support for people stricken by disastrous events in other parts of the Czech Lands, or in further parts of the Austrian empire. For example, on 10 May 1845, the office of the Nové Syrovice estate wrote to the regional office in Znojmo concerning 10 gulden in assistance for people affected by a March flood around the Vltava and Elbe rivers (S12; for more on this flood, see Brázdil et al., 2005). On 8 March 1830, a collection was announced for people around the River Danube affected by a flood that occurred on the night of 28 February/1 March (see Munzar, 2000). Contributions from the Valtice estate amounted to 323 gulden 45 kreutzer (S5). Another record from the regional office, dated 24 March 1838, refers to support for direly afflicted people in Hungary. Although no direct report of flood appears here, this referred to an ice flood that practically destroyed the towns of Pest and Óbuda (now Budapest), together with their suburbs (see Kiss, 2009a). In the end, support from the Valtice estate amounted to 86 gulden 55 kreutzer (S5).

The evaluation and interpretation of such taxation data have enabled the creation of a database of floods in the period, with information about the types of event, the times of occurrence, places and rivers affected, and associated flood impacts. This database has been supplemented by other existing documentary data related to floods, then used for further analyses.

\subsection{Hydrological data}

Since quite comprehensive documentary flood data sets exist and previous studies have been carried out on them (e.g. Brázdil et al., 2005, 2010b, 2011c; Brázdil and Kirchner, 2007), the detailed analysis of floods has tended to centre upon four South Moravian rivers: the Jihlava (a tributary of the River Svratka), the Svratka (a tributary of the River Dyje), the Dyje (a tributary of the River Morava), and the Morava (the most important Moravian river). The following stations have been used to describe floods in the instrumental period, with series of measured peak water levels and peak discharges for every river:

i. the Jihlava: water levels - Ivančice (1896-1930), Dolní Kounice (1888-1912), Pohořelice (1889-1930); discharges - Ivančice (1924-2013)

ii. the Svratka: water levels - Brno-Pisárky (18881924), Židlochovice (1875-1924); discharges - BrnoPisárky/Poříčí (1918-2013), Židlochovice (1921-2013)

iii. the Dyje: water levels - Hevlín (1889-1932), Dolní Věstonice (1889-1920), Břeclav (1889-1912); discharges - Dolní Věstonice (1922-1988), Ladná (19872013)

iv. the Morava: water levels - Kroměříz (1881-1915), Napajedla (1881-1920), Uherské Hradiště (18811920), Uherský Ostroh (1881-1920); discharges - Rohatec/Strážnice (1920-2013).

Some recalculation was required in order to create final water level series, bringing the water levels measured to the same water-gauge zero and allowing for changes in altitude of the given station during the period studied.

\section{Methods of data analysis}

The types of flood emerging from interpretation of taxation records were divided into three categories:

i. ("standard") floods related to overflow from any particular river and originating after heavy precipitation (in the order of a few days), snowmelt or ice jam, usually documented from a large number of locations around the river involved;

ii. flash floods, perhaps even muddy floods (Stankoviansky, 2009; Stankoviansky et al., 2010), after torrential rainfall, with streaming water and great local damage; 
iii. inundation of fields and meadows after very heavy downpours without indication of water leaving its river channels or streaming floodwater.

To present the temporal variability of the entire flood data set, all relevant records and individual flood events derived from taxation evidence have been totalled at annual and decadal levels with respect to the three flood types mentioned in points (i)-(iii) in this section. The spatial variability of flood data is presented as the number of floods obtained for selected rivers in South Moravia and given in order of century.

However, the emphasis of this paper lies with the "standard" floods derived from taxation records that may be clearly attributed to a particular river and are important to the creation of long-term flood chronologies. Such information facilitates analysis of their temporal and spatial changes, with particular focus on their frequency and seasonality; this is particularly valuable for the Jihlava, Svratka, Dyje and Morava rivers. The decadal frequencies of floods are presented for each of these rivers over the whole period covered by taxation records and other documentary data. The information may partly overlap with the instrumental period, in which floods are based on water level and discharge measurements. Selection criteria in the instrumental period consist of flood events based on peak water levels $H_{k} \geq \mathrm{H}_{2}\left(H_{2}\right.$ is a peak water level with a recurrence interval of $N=2$ years) combining several water-gauge stations, and peak discharges $Q_{k} \geq Q_{2}$ ( $Q_{2}$ is a peak discharge with a recurrence interval of $N=2$ years) from one or two stations reported in Sect. 3.2. While $\mathrm{Q}_{N}$ values were provided directly by the Czech Hydrometeorological Institute, peak water levels $H_{N}$ $(N=2,5,10,20,50$ and 100) were calculated for individual stations from maximum annual $H_{k}$ series according to three-parameter generalised extreme value distribution (distribution parameters estimated by the maximum likelihood method; Katz et al., 2002).

Compiled synthesis series of flood frequency finally collate events derived from documentary data, water levels and discharges. In the periods of overlap, floods derived from measurements were preferred to those extracted from documentary data. All floods were further divided into those related to winter synoptic type (occurring from November to April) and to summer synoptic type (from May to October), after Kakos (1983). This division also reflects triggering factors - snowmelt with rain and/or ice jam in the former, and intense rainfall for several days in the latter.

\section{Results}

\subsection{Spatio-temporal changes of floods from taxation data}

Flood information derived from taxation records was categorised by watercourse (or part of it for the larger rivers) in South Moravia. The flood events extracted for our database
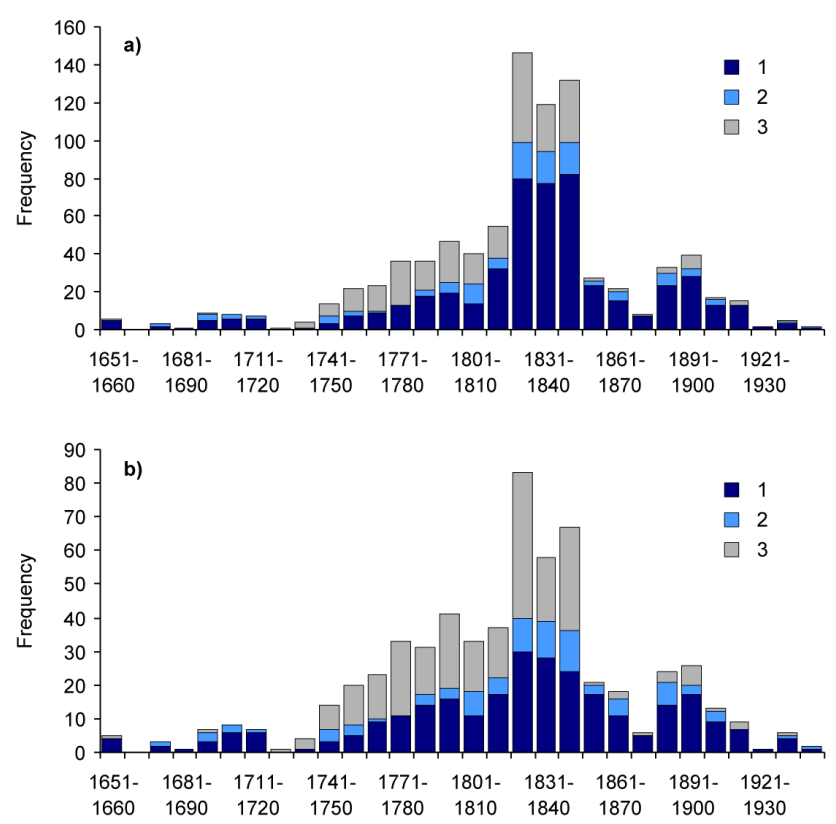

Figure 4. Decadal numbers of (a) taxation records related to floods and (b) flood events derived from taxation records in South Moravia, arranged by flood (1), flash flood (2) and inundation (3).

give general coverage of the time between 1652 and 1941, with many gaps and at differing densities of data. The earliest record of such an event dates to 30 July 1652, from the archives of the Kounic family, reporting water damage following downpour and hailstorm around Lanžhot (S15). Another report describes the flooding of several communities around the Jihlava and Oslava rivers on 16 July 1653 , with damage to buildings, livestock, watermills and meadows (covered in sediment), the failure of six fish-cultivation ponds and both soil and grain crops washed from the fields (S15). The most recent report refers to a flood in March 1941 and lists damage done by the Dyje and Morava rivers in southeastern Moravia (S4).

Figure 4a shows the total decadal numbers of taxation reports related to floods. Although overall totals do not include several documents related to the same event, it gives an indication of the temporal distribution. This may, in turn, partly reflect periods of flood activity and, to a higher degree, the number of documents that have survived to be examined. The majority of the 879 flood-related taxation records related to South Moravia (with a few referring to other parts of the Czech Lands as well) is concentrated around 18211850 (45.2\% of all cases), from which numbers decrease towards the mid-17th century as well as towards the mid20th century. More than 30 records per decade accumulated in 1771-1850 and 1881-1900. The decadal numbers of flood events detected and shown in Fig. 4b indicate some coincidence with the numbers of records. The 1821-1850 period maintains its predominance with $34.6 \%$ of floods from a total of 602 events detected. Also notable is an increase in the 
Table 1. Comparison of floods with peak discharges $Q_{k} \geq Q_{2}$ for four selected South Moravian rivers in 1931-2010: $P$ - catchment area above the station; TF - total number of floods; WF (SF) - number of winter (summer) floods; $Q_{N}$ - number of floods with a recurrence interval of $N=2,5,10,20,50$ and 100 years; $Q_{\max }$ - absolute peak discharge and date of its occurrence. The Ladná station replaced Dolní Věstonice in $1987 ;{ }^{*}-P$ for the Ladná station is $12280 \mathrm{~km}^{2}$.

\begin{tabular}{|c|c|c|c|c|c|c|c|c|c|c|c|c|}
\hline \multirow[t]{2}{*}{ River-station } & \multirow[t]{2}{*}{$P\left(\mathrm{~km}^{2}\right)$} & \multirow[t]{2}{*}{$\mathrm{TF}$} & \multirow[t]{2}{*}{ WF } & \multirow[t]{2}{*}{$\mathrm{SF}$} & \multicolumn{6}{|c|}{$Q_{N}$} & \multicolumn{2}{|c|}{$Q_{\max }$} \\
\hline & & & & & 2 & 5 & 10 & 20 & 50 & 100 & $\mathrm{~m}^{3} \mathrm{~s}^{-1}$ & Date \\
\hline Jihlava-Ivančice & 2682 & 22 & 16 & 6 & 15 & 2 & 2 & 2 & 1 & - & 350 & 22 Mar 1947 \\
\hline Svratka-Židlochovice & 3940 & 28 & 20 & 8 & 17 & 7 & 2 & - & 1 & 1 & 520 & 11 Mar 1941 \\
\hline Dyje-Dolní Věstonice/Ladná & $11740^{*}$ & 34 & 25 & 9 & 19 & 9 & 4 & - & _- & 2 & 863 & 12 Mar 1941 \\
\hline Morava-Strážnice & 9147 & 54 & 29 & 25 & 28 & 18 & 5 & _- & 2 & 1 & 810 & 14 Jul 1997 \\
\hline
\end{tabular}

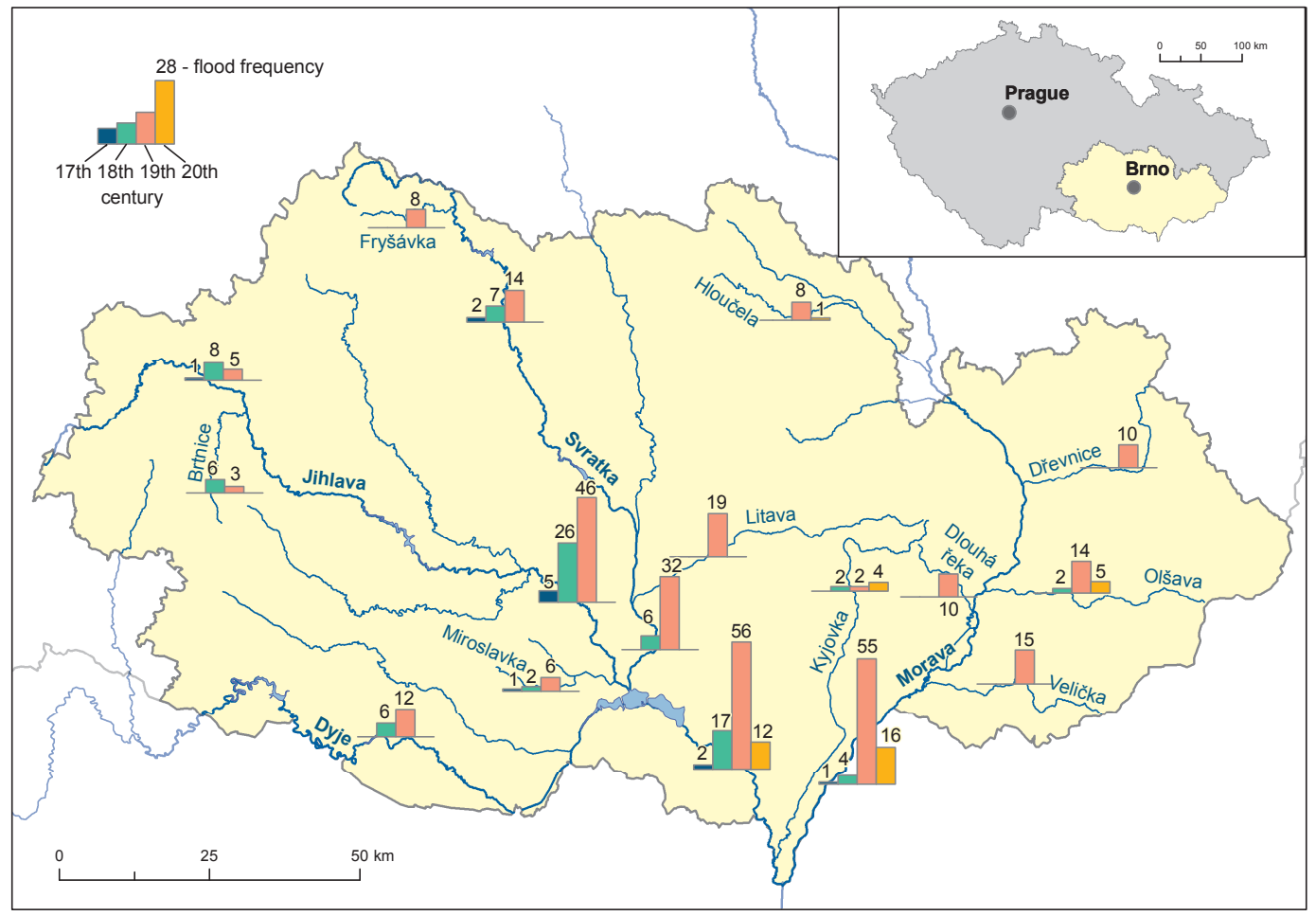

Figure 5. The numbers of floods detected in taxation records and attributed to individual rivers or their parts in South Moravia by the century, from the 17 th to the 20 th.

frequency of flood events in 1791-1800 (41) when in the remaining decades between 1770 and 1820 more than 30 floods occurred per decade. At $46.0 \%$ of the total, "standard" floods prevail in the total number of flood events, followed by inundation events $(39.2 \%)$ and flash floods $(14.8 \%)$. Figure 4 does not include floods indicated by requests for aid to communities outside the Czech Lands, some 32 records describing 14 flood events between 1830 and 1846 in Austria, Hungary, Italy and Poland.

Figure 5 shows the spatial distribution of floods detected from taxation data for individual South Moravian rivers, or parts of them, for which the total number of floods was at least eight. The highest number emerged for the lower reaches of the Dyje (87 cases), followed by the Jihlava (77), the Morava (76) and the Svratka (38). The number of floods in their upper parts and other rivers in South Moravia (with only standard floods and flash floods taken into account) is significantly lower compared to these four. The highest number was 23 for the upper Svratka, followed by 21 for the Olšava, 19 for the Litava, 18 for the upper Dyje, 15 for the Velička and 14 for the upper Jihlava. Only 8 to 10 floods could be extracted from taxation records for the other 7 rivers. In terms of particular centuries, and in agreement with previous results, they occurred most frequently during the 19th century, particularly in its first half. The number of floods interpreted for the 18th century was higher than for the 19th on the upper Jihlava and on the Brtnice. 

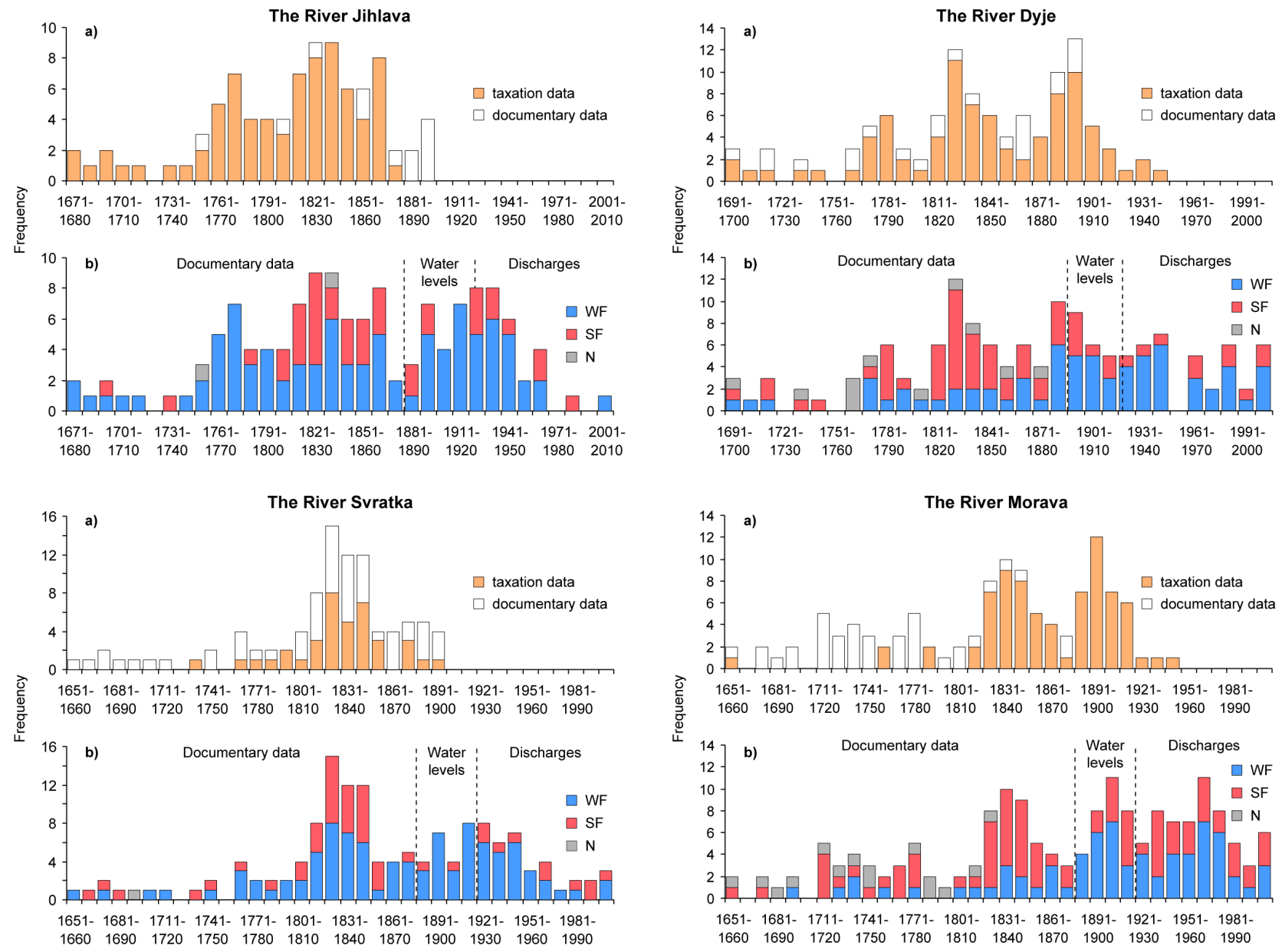

Figure 6. Long-term series of decadal flood frequency combining data derived from documentary (taxation and other documentary data) and instrumental (water levels, discharges) data for the Jihlava, Svratka, Dyje and Morava rivers in South Moravia: (a) series based on documentary data, (b) series compiled from documentary and instrumental data (WF - winter flood, SF - summer flood, N - unclear).

\subsection{Long-term flood chronologies}

The number of floods derived from taxation records was high enough to select only the Jihlava, Svratka, Dyje and Morava rivers for further analysis. To shed more light on differences in their flood regimes, these are further compared for the common 1931-2010 period, based on discharge measurements in Table 1. The highest total number of floods was recorded for the Morava at Strážnice (54), the lowest for the Jihlava at Ivančice (22). Winter floods prevailed at all stations with proportions from $73.5 \%$ for the River Dyje to $53.7 \%$ for the Morava (the Jihlava $72.7 \%$, the Svratka $71.4 \%$ ). While winter floods reached absolute $Q_{\max }$ in March 1947 (with $Q_{50}$ ) for the Jihlava and in March 1941 (with $Q_{100}$ ) for the Svratka and Dyje rivers, $Q_{\max }$ on the River Morava was achieved for a summer flood in July 1997 (with $Q_{100}$ ).

Long-term flood chronologies for the four rivers analysed are further presented separately for documentary data and synthesis series (based on documentary data, water levels and discharges) expressing decadal frequencies of floods in Fig. 6.

The flood frequency series for the River Jihlava relates to the section from Ivančice to the mouth in the Svratka (now to the Nové Mlýny reservoir) (Fig. 1). Its taxation data start with the earliest recorded flood, 4 March 1677, and finish with that of February 1876. The frequencies are probably underestimated before 1750 due to lack of taxation documentation and other reliable records (Fig. 6). Further documentary sources supplement the taxation records only partly, adding 12 new floods (i.e. only $13.5 \%$ of all documentarybased floods). The highest decadal frequencies occurred in 1821-1840 (nine floods for each decade) followed by 1861 1870 (eight floods), 1771-1780 and 1811-1820 (seven floods each). Water-level measurements from the Ivančice, Dolní Kounice and Pohořelice stations cover the 1888-1923 period (i.e. there is a lack of data from 1877 to 1887). This is followed by floods derived from discharges at the Ivančice 
station (no other long-term station with discharge exists for the stretch from Ivančice to the mouth of the river to the Svratka/Nové Mlýny). Combining flood frequencies from instrumental measurements with the pre-instrumental period shows that only 1921-1940, with eight floods per decade, comes close to the decadal maxima in the first half of the 19th century. Especially notable are the four final decades, with no flood in 1971-1980 and 1991-2000, and only one flood each in 1981-1990 and 2001-2010 for this part of the river.

For the purposes of the current work, the River Svratka is taken as the section from the recent Brno reservoir (northwest of the town) to its confluence with the Dyje (more recently, its mouth in the Nové Mlýny reservoir) (Fig. 1). The earliest Svratka flood derived from taxation records dates to 22 June 1734 and the series of such records ends with a flood on 6-7 March 1891. While floods based on taxation emerge largely for the agriculturally exploited area to the south of Brno, the overall flood chronology is greatly extended by other documentary sources (e.g. newspapers) originating in the Brno area (see Brázdil et al., 2010b). The 38 floods derived from taxation data make up only $40.4 \%$ of documentary-based flood events. The 1821-1830 (15 floods) and 1831-1840/1841-1850 (12 floods each) decades dominate in terms of flood activity (Fig. 6). Water-level measurements from the Brno-Pisárky and Židlochovice stations cover the 1875-1920 period, followed by discharge series for the two stations. While the Brno-Pisárky/Poříčí station records the highest decadal numbers for flood frequency between 1821 and 1850 (13 in 1931-1940 and 12 in 1921-1930; see Brázdil et al., 2010b), the Židlochovice station has considerably fewer (only 8 floods per decade in 1911-1930 and 7 in 1941-1950). Despite a significant decline in flood frequency after 1950 (e.g. one flood in 1971-1980 and two per decade in 1981-2000), the figures of none or one/two floods per decade between 1651 and 1760 do not necessarily express the actual situation, potentially reflecting missing data in these scores.

In this study, the River Dyje is taken as the part from the Drnholec area to its confluence with the River Morava (Fig. 1). The taxation data start with a flood on 12 May 1693 and extends to one on 27 March 1941. The 87 floods derived from taxation records make up $79.1 \%$ of all documentarybased events revealed to date. The highest number of detected floods occurs in 1891-1900 (13) followed by 12 in 1821-1830 and 10 in 1881-1890 (Fig. 6). The decadal number of floods between 1691 and 1770 fluctuates between zero and three, as it does in 1791-1810. Water-level measurements taken by the Hevlín, Dolní Věstonice and Břeclav stations span the 1889-1921 period; from 1922 they are based on discharges measured at the Dolní Věstonice station, replaced in 1987 by Ladná after the establishment of the Nové Mlýny dam complex. Flood frequencies in the instrumental period lag behind those of the pre-instrumental period: a maximum of 9 floods was recorded for 1891-1900 (compared with 13 derived from documentary evidence), and only 7 floods in 1941-1950. On the other hand, no flood at all occurred in 1951-1960 and only two per decade in 19711980 and 1991-2000.

The River Morava is represented by the section from Kroměřiž to its confluence with the River Dyje (Fig. 1). Floods derived from taxation data start with an event recorded for 30 July 1652 and end with one on March 1941. With a total of 76 flood events, they make up $66.7 \%$ of all documentary-based floods disclosed. The highest decadal number of documentary-based floods is a total of 12 in 18911900 , followed by 10 floods in 1831-1840, 9 in 1841-1850 and 8 in 1821-1830 (Fig. 6). The decadal frequencies of floods detected in 1651-1710 fluctuate between zero and two. Water-level measurements at several stations (Kroměříž, Napajedla, Uherské Hradiště, Uherský Ostroh, Lanžhot) cover the 1881-1919 period, extended by discharges measured at the Rohatec/Strážnice station from 1920 onwards. The instrumental period slightly exceeded 1831-1840 with 11 floods in 1901-1910 and 1961-1970, followed by 8 per decade in 4 other decades. In similar fashion to the Dyje, the number of floods derived from documentary data in 18911900 was higher than that from water-level measurements (12 against 8). Only the rate of three floods in 1991-2000 is comparable with the frequency of floods that occurred in several decades of the pre-instrumental period.

\section{Discussion}

Figure 6 clearly demonstrates the key importance of taxation data in the development of four long-term flood chronologies in the pre-instrumental period. Floods derived from taxation sources make a different and invaluable contribution, representing between $40.4 \%$ (the Svratka) and $86.5 \%$ (the Jihlava) of all documentary-based floods detected. Despite a greater inter-decadal variability of flood frequency, the floodrich periods for all four rivers are c. 1821-1850 and 19211950. A higher flood frequency also occurred in 1891-1900 (Dyje, Morava). The fluctuations in floods in the current paper coincide to varying degrees with existing flood series for the Czech Lands derived from similar methodological backgrounds. For example, floods on the Svratka and Svitava rivers at Brno reached maximum frequency in 18101850 and 1920-1951 (Brázdil et al., 2010b). On the Bečva, a tributary of the Morava, the highest frequency of floods in documentary sources has been reported for 1711-1720 and to a considerable degree for 1871-1900 (Brázdil and Kirchner, 2007). At the other end of the Czech Lands, the Bohemian rivers reached their highest flood frequency for the past 300 years in the 19th century (the Vltava in 1851-1900, the Elbe and the Ohře in 1801-1850) (Brázdil et al., 2005), while a middle part of the River Morava had its maxima in 1901-1950. The period of high flood frequency in 18211850 also partly coincides with an analysis of 12 Central 
European rivers made by Glaser et al. (2010), who identified $1790-1840$ as a flood-rich period.

Further, the chronology of floods on the River Morava in this paper reveals a lower flood frequency in the preinstrumental period compared with Brázdil et al. (2011c), in which the section of the Morava from Olomouc to Rohatec was studied. Excluding floods recorded in Olomouc itself in the 1691-1800 period (mainly derived from the diaries of the Premonstratensian Abbey at Hradisko between 1693 and 1783; see Brázdil et al., 2011a) led to a loss of 28 events, since they were not replaced by information from any other documentary source along the river, from Kroměríz to the south (Fig. 1).

Despite the importance of taxation data for the study of floods in South Moravia, a number of uncertainties involved in this type of documentary evidence, particularly in interpretation of results, have to be considered. The first drawback involves the spatial and temporal heterogeneity of data, although this is generally typical of all documentary evidence (Brázdil et al., 2006, 2012a). Taxation documents constituted only a tiny part of the running volume of administrative records; moreover, their importance waned sharply once tax relief had been awarded and whether they were retained further was up to the estate owner or relevant authority. Such documents were not only discarded at basic level but also during routine archive maintenance (e.g. Kocman et al., 1954).

Because taxation documents are derived from damage that provides clear reasons for tax relief, the power to detect floods tends to be limited to the vegetation period, particularly to the months from May to August. Summer floods inundated meadows and pastures, destroying hay or aftermath, often depositing various kinds of alien transported material. In similar fashion, forests around rivers in the floodplain suffered the economic consequences of flooding, not least the destruction of habitat for wild game. Arable fields could be eroded away or covered in layers of transported sand and gravel, while more mature crops were destroyed. Winter floods were mentioned only when damage was done by ice floes to buildings, bridges, weirs, and water-mills, or when protection dikes and the retaining walls of fish cultivation ponds failed. As a result of all this, we generally find a higher number of summer floods, some of which may have even been hydrologically weaker than winter floods that attracted no particular notice. This is highlighted quite clearly by comparison between the proportions of summer floods in terms of their total numbers from taxation records and from instrumental data: the Jihlava: $35.1 \%$ against $25.5 \%$; the Svratka: $68.4 \%$ against $20.3 \%$; the Dyje: $63.2 \%$ against $28.8 \%$; and the Morava: $67.1 \%$ against $41.8 \%$.

The variety of ways in which damage was reported in taxation reports, together with incompleteness of the taxation documentation record, also make it difficult to order floods according to their severity. In the light of such classifications of floods as those presented by, for example, Sturm et al. (2001), Barriendos and Coeur (2004) and Bullón (2011), interpretation of the flood severity for South Moravian rivers would be highly speculative and direct comparison impossible. Indeed, in the latter, only seldom does any comparison appear of the water level of a given flood with that of some previous event. One such example, comparing the February 1794 flood on the River Jihlava with those of 1775, has already been cited in Sect. 3.1 (S8). Another report for the same river mentions that the water level during a spring flood in 1865 was 2.5 feet $[79 \mathrm{~cm}]$ below that of the February 1862 flood (S10; for the latter flood see Brázdil et al., 2005). A similar episodic entry relates to a flood on 3 March 1838 at Židlochovice, where the level of the River Svratka exceeded that of an event on March 1830 (S7).

The above problems, of the more frequent recording of summer floods and in the classification of flood severity, may be examined by comparing floods derived from taxation data with local maxima of measured water levels at water-gauge stations (Fig. 7). For example, on the Dyje in 1890 , two floods are reported in taxation data: $\sim 29-30$ January and $\sim 24$ March. These two events correspond to water levels measured at Dolní Věstonice and Břeclav, but four other comparable water-level peaks (17-19 April, 1-3 May, 5-7 September and 26-28 November) remain unnoticed in archival material to date (Fig. 7a). On the River Morava in 1896, taxation records mention floods before 27 May and around 13 August. While the highest water level based on measurements at the Brodské and Lanžhot stations occurred on 8 May (Lanžhot 12-13 May), on 13 August the water level did not achieve other local maxima that occurred on 12 March, 28-29 March and 8 September (Fig. 7b). Some agreement between documents and measurements was achieved for 1897, when taxation data and water levels tallied for flood peaks in August and May, but high measured water levels from March to early April (with a peak on 7 March) were not reflected in taxation data (Fig. 7c).

The compilation of long-term flood chronologies requires a basic understanding of flood processes. Based on documentary data, a flood described a situation in which the river left its channel and inundated the floodplain. Furthermore, for taxation data, it had, by its very nature, to be accompanied by some account of damage in order for the consequent request for tax relief to be processed. Based on instrumental hydrological data, floods are defined by a statistical approach, in terms of peak values corresponding to a given recurrence interval $N$ (in this study $N \geq 2$ years). Moreover, depending on channel capacity, the river need not even inundate the floodplain and do damage. For example, the modern channel of the River Morava in the area of Strážnické Pomoraví has the capacity to carry a discharge equivalent to a 5-year flood $Q_{5}$ (Brázdil et al., 2011b).

The character of rivers and their floodplains over time has also to be taken into consideration. These have changed significantly over the past c. 360 years. In the past, the meandering character of rivers, their various lateral channels 

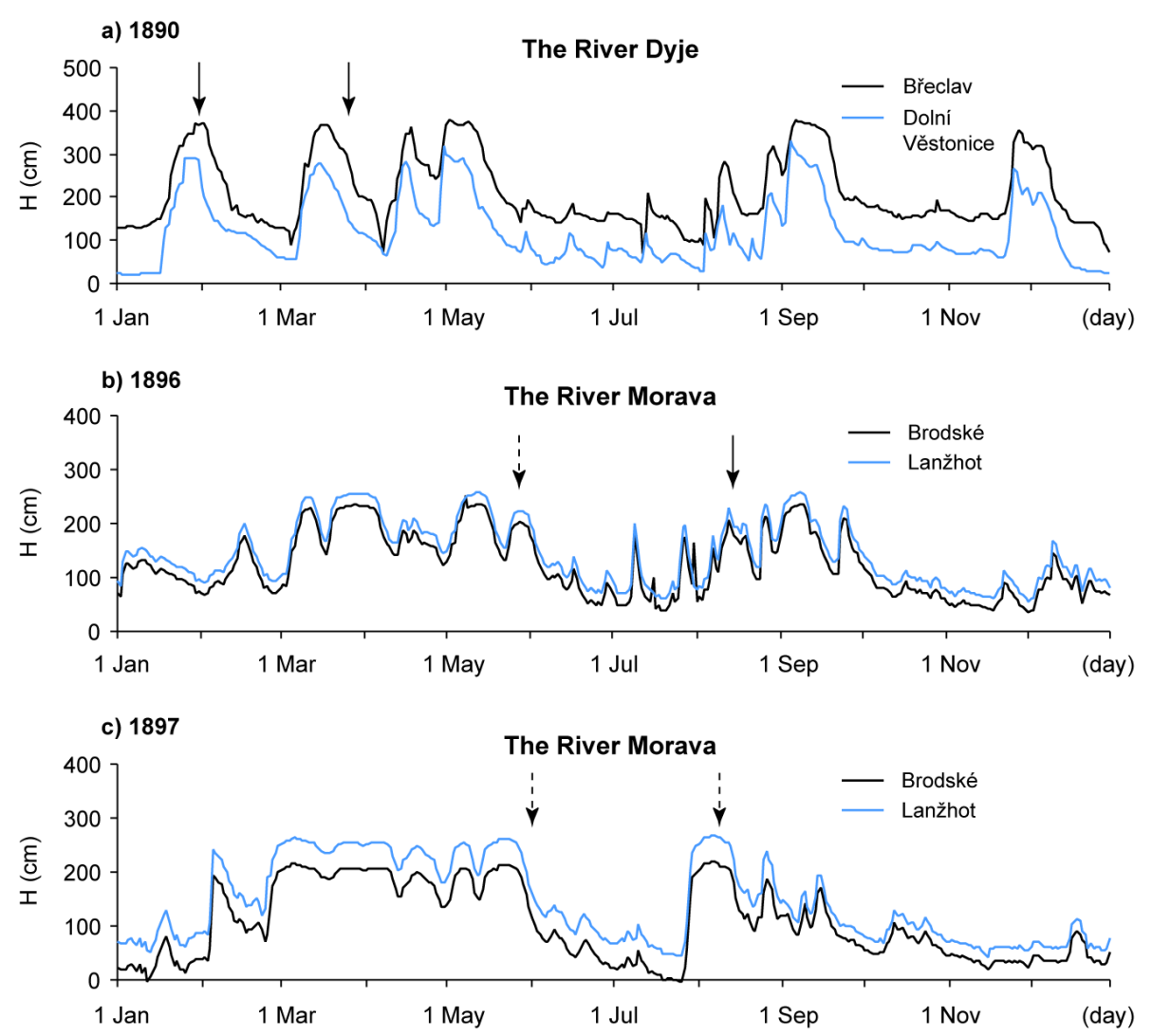

Figure 7. Comparison of floods derived from taxation records with fluctuations of daily water levels measured at water-gauge stations (0 always corresponds to zero of a given water gauge): (a) 1890: River Dyje, Břeclav and Dolní Věstonice stations, (b) 1896: River Morava, Brodské and Lanžhot stations, (c) 1897: as (b). Arrows mark floods derived from taxation records (broken arrows indicate a flood before that date).

alongside the main stream, and the many weirs and millraces led to far more frequent inundations of floodplains itself represented more particularly by pastures, meadows or floodplain forest. Anthropogenic effects on a given catchment have also been reflected in land-use changes that influence ground water-holding capacity and the whole runoff process (Hall et al., 2014). Direct anthropogenic effects on river channels consist largely of water regulation (channel straightening in particular) and the building of various waterbased constructions, as well as the expansion of various human activities in the floodplains. All of these have intensified, especially during the 20th century with the building of water reservoirs.

Some changes in channel are recorded for the Jihlava and Svratka rivers and the area in which they join the Dyje (Fig. 8a). A comparison of situations using the General Map of the Moravian Margraviate (based on the Second Austrian Military Survey of 1836-1840) and a more recent one (2012) reveals a heavily modified landscape, created by the construction of the large Nové Mlýny reservoir on the River Dyje. This system of three reservoirs was built between 1974 and 1988 with an area of 3232 ha. Other reservoirs on the upper Dyje at Vranov nad Dyjí and Znojmo have been in operation from 1934 and 1965, respectively. Reservoirs also exist in the upper reaches of the Jihlava (Dalešice and Mohelno since 1979) and Svratka (Brno since 1940, Vír I and Vír II since 1957) rivers (Broža et al., 2005). Skokanová (2005) made a detailed study of channel changes in the River Dyje between 1830 and 2001 in the section from the Austrian border near Nový Prrerov, close to the confluence with the Morava. The Dyje in this reach has been reduced in length from 92.3 to $70.7 \mathrm{~km}$ and the sinuosity of the channel decreased by $\sim 70 \%$. The first channel adjustments started around 1822, then continued in 1888-1902, 1911 and 1934, later particularly in 1975-1988 (Skokanová, 2005, 2008). Like the Dyje, the River Svratka has clearly been reduced in length and in the sinuosity of its channel. For example, its channel from the conjunction with the Svitava to the mouth in the Dyje was reduced by $36 \%$ between the mid-19th century and the present (see Brázdil et al., 2010b for more detail). On the other hand, the Jihlava shows no dramatic channel changes.

For the River Morava (Fig. 8b), various anthropogenic effects with detail of changes to the Morava floodplain in 
a)

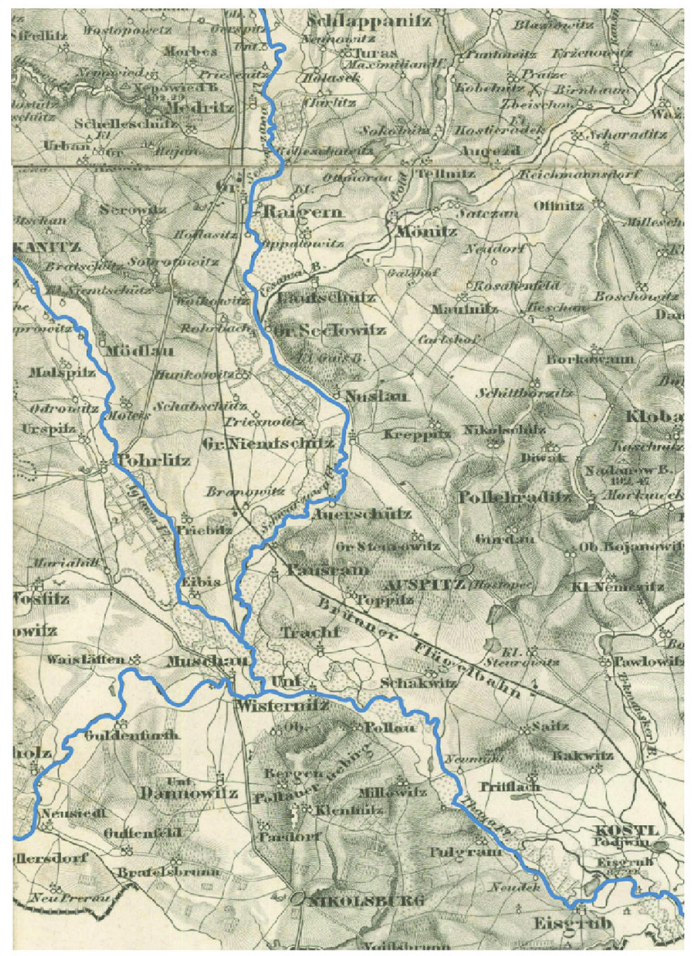

b)

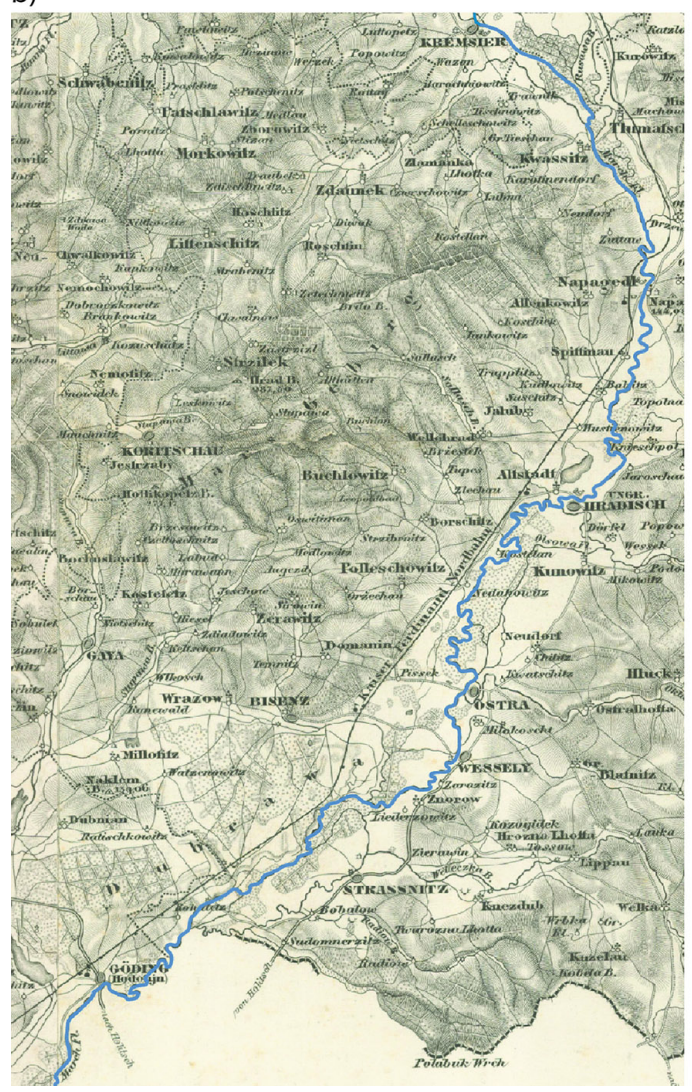

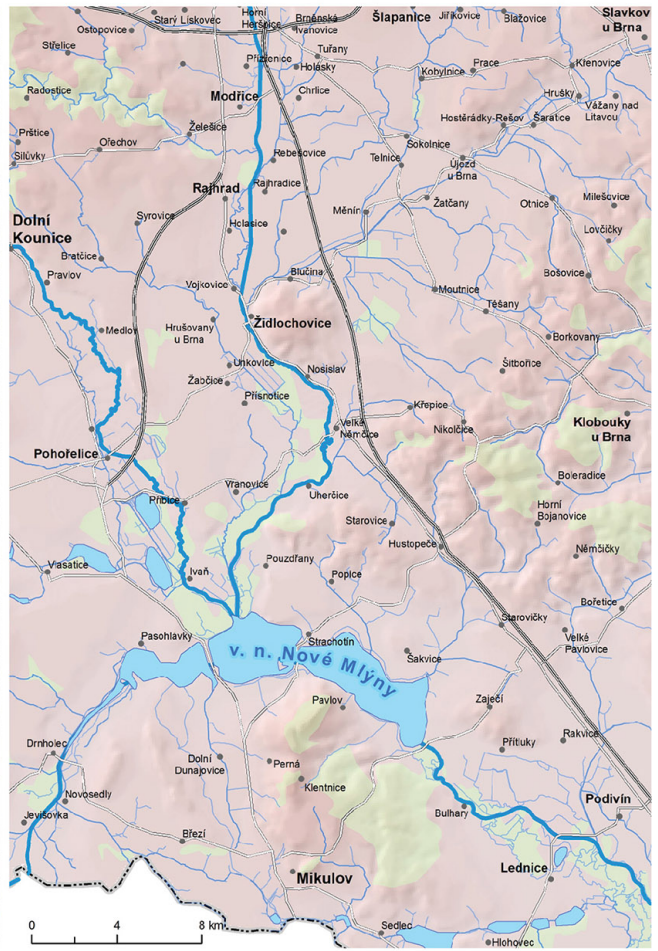

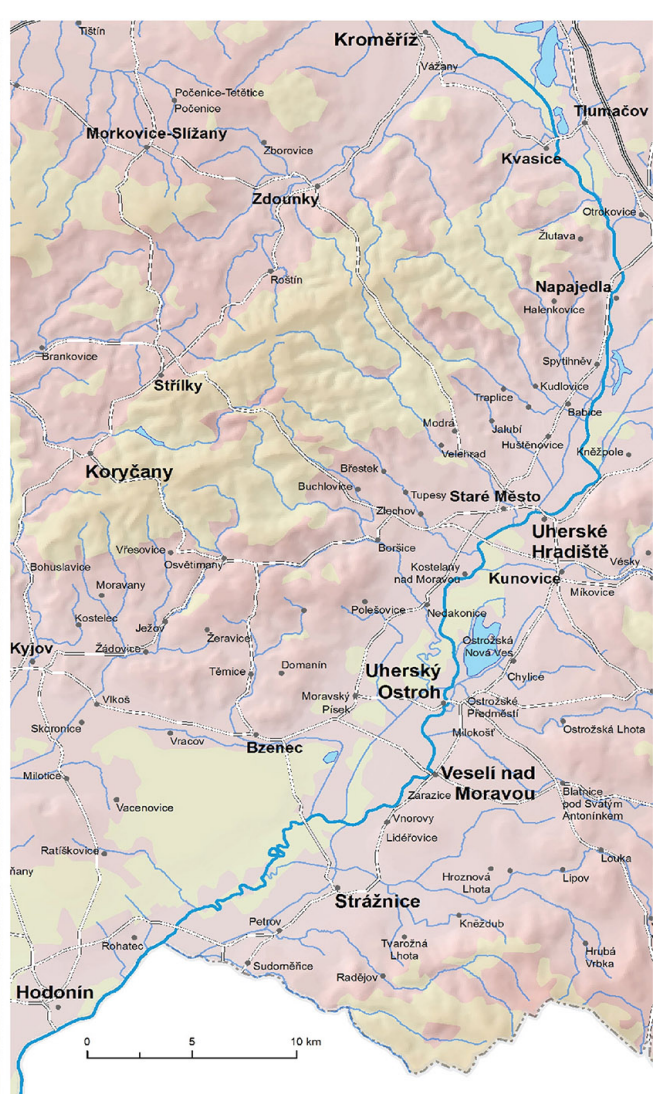

Figure 8. Changes in situation on sections along selected South Moravian rivers: (a) the Jihlava, Svratka and Dyje, (b) the River Morava. The situation as per the General Map of the Moravian Margraviate (General-Karte, 1846, left panels) is compared with a recent map (2012, right panels). The rivers in question are highlighted. 
the Strážnické Pomoraví region have been described by Brázdil et al. (2011b, c). Channel regulation was particularly influential between Napajedla and Rohatec. In the Strážnické Pomoraví region, the natural dynamics of the original anabranching channel patterns of the Morava were significantly modified by human intervention, including the abandonment of some anabranching channels, main channel straightening and enlargement, flood-dike construction, and the creation of a shipping channel for Bat'a Enterprises (Brázdil et al., 2011b). From changes in land use between 1836 and 2006, reflected in the retention capacity of the landscape, it follows that $59.2 \%$ of the entire Morava catchment was once in stable use (mainly forest and arable land). Significant changes have included a 2.5 -fold decrease in the area of permanent grassland and a 3-fold increase in built-up areas in the floodplains and lowlands (Brázdil et al., 2011c).

\section{Conclusions}

Despite a number of limitations and uncertainties - arising largely out of the focus of taxation documents upon the finance of tax relief due because of damage done to buildings, water-based equipment, fields, meadows, pastures, gardens, vineyards, fishponds and forests - information about floods, the places and rivers of their occurrence, sometimes even about the course of a given flood and its causes, may be obtained. In many cases such information is original (i.e. not previously known from other documentary evidence) or overlaps with a flood message derived from another source (i.e. may verify it or contribute to increasing its accuracy or extension). As this paper demonstrates, taxation data have proved a key documentary source for compilation of longterm flood chronologies for four selected rivers in South Moravia, Czech Republic. Without the floods thus interpreted from such data, our knowledge about flood frequency on the Dyje, Jihlava, Svratka and Morava rivers in the preinstrumental period would be very limited. Moreover, the series obtained provide basic long-term flood chronologies that may be used further for the study and better understanding of changes in flood frequency or seasonality. This is in accord with a paper by Hall et al. (2014) reporting that long-term flood chronologies combining documentary and instrumental data are of key importance to the better understanding of flood regime changes at various spatial scales on the European level.

Despite the extremely time-consuming process of working through taxation data, interpreting it and evaluating it, the facts derived have great potential for extending our knowledge of past floods. This remains valid not only for the rest of the Czech Republic but also extends to many other European countries. Similarly, the great potential thus opened up is not confined to the use of these data sets in just historical hydrology and climatology; it is also directly applicable to history studies, especially those that are environmentally based.

Acknowledgements. The authors gratefully acknowledge the support of the Grant Agency of the Czech Republic for project ref. no. 13-19831S. We would also like to thank Tony Long (Svinošice, Czech Republic) for helping to work out the English.

Edited by: A. Kiss

\section{References}

Barriendos, M. and Coeur, D.: Flood data reconstruction in historical times from non-instrumental sources in Spain and France, in: Systematic, palaeoflood and historical data for the improvement of flood risk estimation, Methodological guidelines, edited by: Benito, G. and Thorndycraft, V. R., Centro de Ciencias Medioambientales, Madrid, Spain, 29-42, 2004.

Barriendos, M. and Rodrigo, F. S.: Study of historical flood events on Spanish rivers using documentary data, Hydrolog. Sci. J., 51, 765-783, doi:10.1623/hysj.51.5.765, 2006.

Benito, G., Diéz-Herrero, A., and Fernández de Villalta, M.: Magnitude and frequency of flooding in the Tagus basin (Central Spain) over the last millennium, Climatic Change, 58, 171-192, doi:10.1023/A:1023417102053, 2003.

Blöschl, G., Nester, T., Komma, J., Parajka, J., and Perdigão, R. A. P.: The June 2013 flood in the Upper Danube Basin, and comparisons with the 2002, 1954 and 1899 floods, Hydrol. Earth Syst. Sci., 17, 5197-5212, doi:10.5194/hess-17-5197-2013, 2013.

Brázdil, R. and Kirchner, K. (Eds.): Vybrané přírodní extrémy a jejich dopady na Moravě a ve Slezsku (Selected natural extremes and their impacts in Moravia and Silesia), Masarykova univerzita, Český hydrometeorologický ústav, Ústav geoniky Akademie věd České republiky, v.v.i., Brno, Praha, Ostrava, Czech Republic, 432 pp., 2007.

Brázdil, R. and Valášek, H.: Use of historic data in studying damage due to natural disasters at the domain of Pernštejn in the period 1694-1718 and as a source of information for the study of meteorological and hydrological extremes, Meteorologický časopis, 6, 3-13, 2003.

Brázdil, R., Dobrovolný, P., Elleder, L., Kakos, V., Kotyza, O., Květoň, V., Macková, J., Müller, M., Štekl, J., Tolasz, R., and Valášek, H.: Historické a současné povodně v České republice (Historical and recent floods in the Czech Republic), Masarykova univerzita, Český hydrometeorologický ústav, Brno, Praha, Czech Republic, 370 pp., 2005.

Brázdil, R., Kundzewicz, Z. W., and Benito, G.: Historical hydrology for studying flood risk in Europe, Hydrolog. Sci. J., 51, 739764, doi:10.1623/hysj.51.5.739, 2006.

Brázdil, R., Demarée, G. R., Deutsch, M., Garnier, E., Kiss, A., Luterbacher, J., Macdonald, N., Rohr, C., Dobrovolný, P., Kolář, P., and Chromá, K.: European floods during the winter 1783/1784: scenarios of an extreme event during the 'Little Ice Age', Theor. Appl. Climatol., 100, 163-189, doi:10.1007/s00704-009-0170-5, 2010a. 
Brázdil, R., Valášek, H., and Soukalová, E. (Eds.): Povodně v Brně, Historie povodní, jejich př́ičiny a dopady (Floods in Brno. A history of floods, their causes and impacts), Statutární město Brno, Archiv města Brna, Brno, Czech Republic, 470 pp., 2010 b.

Brázdil, R., Černušák, T., and Řezníčková, L.: The weather and climate in the region of Olomouc, Czech Republic, based on Premonstratensian diaries kept by the Hradisko monastery and Svatý Kopeček priory, 1693-1783, Masaryk University, Brno, Czech Republic, 272 pp., 2011 a.

Brázdil, R., Máčka, Z., Řezníčková, L., Soukalová, E., Dobrovolný, P., and Matys Grygar, T.: Floods and floodplain changes of the River Morava, the Strážnické Pomoraví region (Czech Republic) over the past 130 years, Hydrolog. Sci. J., 56, 1166-1185, doi:10.1080/02626667.2011.608359, 2011b.

Brázdil, R., Řezníčková, L., Valášek, H., Havlíček, M., Dobrovolný, P., Soukalová, E., Řehánek, T., and Skokanová, H.: Fluctuations of floods of the River Morava (Czech Republic) in the 1691-2009 period: interactions of natural and anthropogenic factors, Hydrolog. Sci. J., 56, 468-485, doi:10.1080/02626667.2011.564175, 2011c.

Brázdil, R., Chromá, K., Valášek, H., and Dolák, L.: Hydrometeorological extremes derived from taxation records for south-eastern Moravia, Czech Republic, 1751-1900 AD, Clim. Past, 8, 467481, doi:10.5194/cp-8-467-2012, 2012a.

Brázdil, R., Kundzewicz, Z. W., Benito, G., Demarée, G., Macdonald, N., and Roald, L. A.: Historical floods in Europe in the past millennium, in: Changes in flood risk in Europe, IAHS Special Publication 10, edited by: Kundzewicz, Z. W., IAHS Press and CRC Press/Balkema, Wallingford, UK, 121-166, 2012b.

Brázdil, R., Řezníčková, L., Havlíček, M., and Elleder, L.: Floods in the Czech Republic, in: Changes in flood risk in Europe, IAHS Special Publication 10, edited by: Kundzewicz, Z. W., IAHS Press and CRC Press/Balkema, Wallingford, UK, 178198, 2012c.

Broža, V., Satrapa, L., Sakař, K., Bláha, J., Báča, V., Vít, P., Maníček, J., Bíza, P., Jílek, M., Kopřivová, J., and Vinklát, P. D.: Přehrady Čech, Moravy a Slezska (Water reservoirs of Bohemia, Moravia and Silesia), Knihy 555, Liberec, Czech Republic, 251 pp., 2005.

Bullón, T.: Relationships between precipitation and floods in the fluvial basins of Central Spain based on documentary sources from the end of the 16th century, Nat. Hazards Earth Syst. Sci., 11, 2215-2225, doi:10.5194/nhess-11-2215-2011, 2011.

Daňhelka, J. and Kubát, J. (Eds.): Přívalové povodně na území České republiky v červnu a červenci 2009 (Flash floods on the territory of the Czech Republic in June and July 2009), Ministerstvo životního prostř̌edí ČR, Český hydrometeorologický ústav, Praha, Czech Republic, 71 pp., 2009.

Daňhelka, J. and Šercl, P.: Povodně v České republice v roce 2010 (Floods in the Czech Republic in 2010), Meteorologické zprávy, 64, 4-9, 2011.

Dolák, L., Brázdil, R., and Valášek, H.: Hydrological and meteorological extremes derived from taxation records: the estates of Brtnice, Třebíč and Velké Meziříčí, 1706-1849, Hydrolog. Sci. J., 58, 1620-1634, doi:10.1080/02626667.2013.840727, 2013.

Elleder, L.: Reconstruction of the 1784 flood hydrograph for the Vltava River in Prague, Czech Republic, Global Planet. Change, 70, 117-124, doi:10.1016/j.gloplacha.2009.11.012, 2010.
Elleder, L., Herget, J., Roggenkamp, T., and Nießen, A.: Historic floods in the city of Prague - a reconstruction of peak discharges for 1481-1825 based on documentary sources, Hydrol. Res., 44, 202-214, doi:10.2166/nh.2012.161, 2013.

General-Karte: General-Karte der Markgrafschaft Mähren mit den Antheilen Herzogthums Schlesien, K. K. Militaerisches Geographisches Institut, Wien, Austria, 1846.

Glaser, R., Riemann, D., Schönbein, J., Barriendos, M., Brázdil, R., Bertolin, C., Camuffo, D., Deutsch, M., Dobrovolný, P., van Engelen, A., Enzi, S., Halíčková, M., Koenig, S. J., Kotyza, O., Limanowka, D., Macková, J., Sghedoni, M., Martin, B., and Himmelsbach, I.: The variability of European floods since AD 1500, Climatic Change, 101, 235-256, doi:10.1007/s10584-010-98167, 2010.

Hall, J., Arheimer, B., Borga, M., Brázdil, R., Claps, P., Kiss, A., Kjeldsen, T. R., Kriaučiūnienė, J., Kundzewicz, Z. W., Lang, M., Llasat, M. C., Macdonald, N., McIntyre, N., Mediero, L., Merz, B., Merz, R., Molnar, P., Montanari, A., Neuhold, C., Parajka, J., Perdigão, R. A. P., Plavcová, L., Rogger, M., Salinas, J. L., Sauquet, E., Schär, C., Szolgay, J., Viglione, A., and Blöschl, G.: Understanding flood regime changes in Europe: a state-of-the-art assessment, Hydrol. Earth Syst. Sci., 18, 27352772, doi:10.5194/hess-18-2735-2014, 2014.

Hančarová, E., Metelka, L., Mrkvica, Z., Pavlík, J., Pozler, R., Šiftař, Z., Váchal, P., and Veselý, R.: Katastrofální povodeň v podhưří Orlických hor ve dnech 22. až 25.7.1998 (Catastrophic flood in foothills of the Orlické hory Mountains on 22-25 July 1998), Meteorologické zprávy, 52, 1-12, 1999.

Herget, J. and Meurs, H.: Reconstructing peak discharges for historic flood levels in the city of Cologne - Germany, Global Planet. Change, 70, 108-116, doi:10.1016/j.gloplacha.2009.11.011, 2010.

Herget, J., Roggenkamp, T., and Krell, M.: Estimation of peak discharges of historical floods, Hydrol. Earth Syst. Sci. Discuss., 11, 5463-5485, doi:10.5194/hessd-11-5463-2014, 2014.

Hladný, J., Krátká, M., and Kašpárek, L. (Eds.): August 2002 catastrophic flood in the Czech Republic, Ministry of Environment of the Czech Republic, Prague, Czech Republic, 44 pp., 2004.

Hladný, J., Kašpárek, L., Krátká, M., Kněžek, M., and Martínková, M. (Eds.): Katastrofální povodeň v České republice v srpnu 2002 (Disastrous flood in the Czech Republic in August 2002), Ministerstvo životního prostředí, Praha, Czech Republic, 68 pp., 2005.

Kakos, V.: Hydrometeorologický rozbor povodní na Vltavě v Praze za období 1873 až 1982 (Hydrometeorological analysis of the Vltava floods in Prague in the period 1873-1982), Meteorologické zprávy, 36, 171-181, 1983.

Katz, R. W., Parlange, M. B., and Naveau, P.: Statistics of extremes in hydrology, Adv. Water Resour., 25, 1287-1304, doi:10.1016/S0309-1708(02)00056-8, 2002.

Kiss, A.: Historical climatology in Hungary: Role of documentary evidence in the study of past climates and hydrometeorological extremes, Idöjárás, 113, 315-339, 2009a.

Kiss, A.: Floods and weather in 1342 and 1343 in the Carpathian Basin, J. Environ. Geogr., 2, 37-47, 2009b.

Kiss, A. and Laszlovszky, J.: 14th-16th-century Danube floods and long-term waterlevel changes in archaeological and sedimentary evidence in the western and central Carpathian Basin: an overview with documentary comparison, J. Environ. Geogr., 6, 1-11, doi:10.2478/jengeo-2013-0001, 2013. 
Kjeldsen, T. R., Macdonald, N., Lang, M., Mediero, L., Albuquerque, T., Bogdanowicz, E., Brázdil, R., Castellarin, A., David, V., Fleig, A., Gúl, G. O., Kriauciuniene, J., Kohnová, S., Merz, B., Nicholson, O., Roald, L. A., Salinas, J. L., Sarauskiene, D., Šraj, M., Strupczewski, W., Szolgay, J., Toumazis, A., Vanneuville, W., Veijalainen, N., and Wilson, D.: Documentary evidence of past floods in Europe and their utility in flood frequency estimation, J. Hydrol., 517, 963-973, doi:10.1016/j.hydrol.2014.06.038, 2014.

Kocman, A., Musilová, M., Pletka, V., Radimský, J., Švábenský, M., Trantírek, M., Urbánková , L., and Wurmová, M.: Průvodce po Státním archivu v Brně (Guide to the State Archives in Brno), Krajské nakladatelství, Brno, Czech Republic, 590 pp., 1954.

Kundzewicz, Z. W. (Ed.): Changes in flood risk in Europe, IAHS Special Publication 10, IAHS Press and CRC Press/Balkema, Wallingford, UK, 516 pp., 2012.

Macdonald, N.: Reassessing flood frequency for the River Trent, central England, since AD 1320, Hydrol. Res., 44, 215-233, doi:10.2166/nh.2012.188, 2013.

Macdonald, N. and Black, A. R.: Reassessment of flood frequency using historical information for the River Ouse at York, UK (1200-2000), Hydrolog. Sci. J., 55, 1152-1162, doi:10.1080/02626667.2010.508873, 2010.

Macek, J. and Žáček, V.: Krajská správa v českých zemích a její archivní fondy (1605-1868) (Regional administration in the Czech Lands and its archival groups (1605-1868)), Archivní správa ministerstva vnitra, Praha, Czech Republic, 352 pp., 1958.

Matějíček, J.: Povodeň v povodí Moravy v roce 1997 (The flood in the Morava catchment in 1997), Povodí Moravy, Brno, Czech Republic, 109 pp., 1998.

Matějíček, J. and Hladný, J.: Povodňová katastrofa 20. století na území České republiky (Flood disaster of the 20th century on the territory of the Czech Republic), Ministerstvo životního prostředí, Praha, Czech Republic, 60 pp., 1999.

Mudelsee, M., Börngen, M., Tetzlaff, G., and Grünewald, U.: No upward trends in the occurrence of extreme floods in central Europe, Nature, 425, 166-169, doi:10.1038/nature01928, 2003.

Mudelsee, M., Deutsch, M., Börngen, M., and Tetzlaff, G.: Trends in flood risk of the River Werra (Germany) over the past 500 years, Hydrolog. Sci. J., 51, 818-833, doi:10.1623/hysj.51.5.818 2006.

Munzar, J.: Floods in Central Europe after the exceedingly severe winter season 1829/1830, Moravian Geogr. Rep., 8, 45-57, 2000.

Novotný, J.: Moravský berní systém v století XVII. Příspěvek k hospodářským dějinám země (The Moravian tax system in the 17th century. A contribution to the economic history of the land), Časopis Matice moravské, 58, 145-286, 1934.

Roggenkamp, T. and Herget, J.: Reconstructing peak discharges of historic floods of the River Ahr - Germany, Erdkunde, 68, 49-59, doi:10.3112/erdkunde.2014.01.05, 2014.

Rohr, C.: Floods of the Upper Danube River and its tributaries and their impact on urban economies (c. 1350-1600): The examples of the towns of Krems/Stein and Wels (Austria), Environ. Hist., 19, 133-148, doi:10.3197/096734013X13642082568534, 2013.

Schmocker-Fackel, P. and Naef, F.: Changes in flood frequencies in Switzerland since 1500, Hydrol. Earth Syst. Sci., 14, 1581-1594, doi:10.5194/hess-14-1581-2010, 2010.
Šercl, P., Tyl, R., and Pecha, M.: Průběh a extremita povodně v červnu 2013 (The course and the extremity of the June 2013 flood), Meteorologické zprávy, 66, 197-202, 2013.

Šimek, A.: Z minulosti pozemkového katastru země Moravskoslezské, 1. část (From the past of the land registry of the Moravian-Silesian Land, Part 1), Státní nakladatelství, Praha, Czech Republic, 70 pp., 1918.

Skokanová, H.: Změny koryta dolní Dyje v období 1830-2001 způsobené antropogenní činností (Channel changes of the lower part of the Dyje River in the 1830-2001 period caused by human activities), Geografie, 110, 271-286, 2005.

Skokanová, H.: The impact of river engineering works on the Dyje River floodplain in the Czech Republic, Global Environ., 1, 82111, 2008.

Solomon, S., Qin, D., Manning, M., Marquis, M., Averyt, K., Tignor, M. M. B., Miller, H. L., and Chen, Z. (Eds): Climate Change 2007: The physical science basis. Contribution of Working group I to the Fourth assessment report of the Intergovernmental panel on climate change, Cambridge University Press, Cambridge, UK, 996 pp., 2007.

Stankoviansky, M.: Geomorphic effect and environmental impact of current and historical muddy floods in Slovakia, Z. Geomorphol., 53, Supplement 2, 159-170, doi:10.1127/03728854/2009/0053S3-0159, 2009.

Stankoviansky, M., Minár, J., Barka, I., Bonk, R., and Trizna, M.: Muddy floods in Slovakia, Land Degrad. Dev., 21, 336-345, doi:10.1002/ldr.1004, 2010.

Stocker, T. F., Qin, D., Plattner, G.-K., Tignor, M. M. B., Allen, S. K., Boschung, J., Nauels, A., Xia, Y., Bex, V., and Midgley, P. M. (Eds.): Climate Change 2013: The physical science basis. Working group I contribution to the Fifth assessment report of the Intergovernmental panel on climate change, Cambridge University Press, Cambridge, UK, 1535 pp., 2013.

Sturm, K., Glaser, R., Jacobeit, J., Deutsch, M., Brázdil, R., Pfister, C., Luterbacher, J., and Wanner, H.: Hochwasser in Mitteleuropa seit 1500 und ihre Beziehung zur atmosphärischen Zirkulation, Petermann. Geogr. Mitt., 145, 14-23, 2001.

Thorndycraft, V. R., Barriendos, M., Benito, G., Rico, M., and Casas, A.: The catastrophic floods of AD 1617 in Catalonia (NE Spain) and their climatic context, Hydrolog. Sci. J., 51, 899-912, doi:10.1623/hysj.51.5.899, 2006.

Voldán, V., Horák, K., Ježková, M., Kudrnová, P., Kyasová, V., Obršlík, J., Řezníček, J., and Zř́ídkaveselý, F.: Státní archiv v Brně, Průvodce po archivních fondech, svazek 2 (The State Archives in Brno, Guide to archival funds, volume 2), Archivní správa ministerstva vnitra, Praha, Czech Republic, 363 pp., 1964.

Wetter, O., Pfister, C., Weingartner, R., Luterbacher, J., Reist, T., and Trösch, J.: The largest floods in the High Rhine basin since 1268 assessed from documentary and instrumental evidence, Hydrolog. Sci. J., 56, 733-758, doi:10.1080/02626667.2011.583613, 2011.

\section{Archival sources}

(S1) MZA Brno, fond F 16 Velkostatek Brtnice (1537) 1562-1947, inv. č. 371, fol. 106rv, 111r-112v, 114rv, 118r-119v.

(S2) MZA Brno, fond F 18 Hlavní registratura Ditrichštejnů v Mikulově (1249) 1411-1889, inv. č. 7840, fol. 55r-56r. 
(S3) MZA Brno, fond F 43 Velkostatek Břeclav 1520-1946, kart. 237, fol. 103r, 104r.

(S4) MZA Brno, fond F 43 Velkostatek Břeclav 1520-1946, kart. 1304, fasc. 2, sign. J, fol. 2rv, 4rv, 8r, 9rv.

(S5) MZA Brno, fond F 94 Velkostatek Valtice (1391)-1945, inv. č. 528, fol. 335rv, 347rv.

(S6) MZA Brno, fond F 104 Velkostatek Židlochovice (1445)1918, inv. č. 528, fasc. 1736-1741, fol. 1rv, 3r.

(S7) MZA Brno, fond F 104 Velkostatek Židlochovice (1445)1918, inv. č. 603 , fasc. 258 , fol. 30r.

(S8) MZA Brno, fond F 119 Velkostatek Dolní Kounice 1343 (opis)-1899, inv. č. 539, sign. 51, fol. 9rv.

(S9) MZA Brno, fond F 119 Velkostatek Dolní Kounice 1343 (opis)-1899, inv. č. 539, sign. 51, fol. 84rv, 96r.
(S10) MZA Brno, fond F 119 Velkostatek Dolní Kounice 1343 (opis)-1899, inv. č. 540, sign. 51, 1847-1869, fol. 109r-111r.

(S11) MZA Brno, fond F 179 Velkostatek Nové Syrovice (1671) 1703-1943, inv. č. 286 Fach 28, fasc. 1, fol. 246rv.

(S12) MZA Brno, fond F 179 Velkostatek Nové Syrovice (1671) 1703-1943, inv. č. 287 Fach 28, fasc. 1, fol. 169r.

(S13) MZA Brno, fond F 268 Velkostatek Hajany (1690) 17101943, inv. č. 68, fol. 1r.

(S14) MZA Brno, fond G 147 Rodinný archiv Mitrovských (1203)1943, inv. č. 311-314.

(S15) MZA Brno, fond G 436 Rodinný archiv Kouniců Slavkov (1272) 1278-1960, inv. č. 3569, fol. 41r, 42rv, 74rv. 